\title{
A new year
}

\author{
Une nouvelle année
}

A s 2008 becomes part of history, it is appropriate to reflect on the year and comment on the status of the Journal. It has been a difficult year with many challenges - but, as usual, some good things happened as well.

In the business of journals, we always wait one year before we know how we performed in the previous year. So what about 2007? It was the busiest year that we have experienced at The Canadian Journal of Cardiology, with a significant increase in the number of submissions. However, as I have noted in previous issues, this increase in submissions was not associated with a sufficient decrease in acceptance rate to maintain our hoped for average time from acceptance to publication; in other

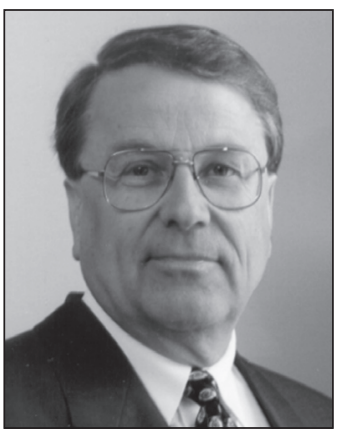

Eldon R Smith
$\mathrm{T}$ andis que 2008 entre dans l'histoire, il convient de réfléchir à l'année et de commenter la situation du Journal. L'année a été difficile et a comporté de nombreux défis, mais comme toujours, de bonnes choses se sont également produites.

Dans le milieu des revues scientifiques, il faut toujours attendre un an pour connaître notre rendement de l'année précédente. Alors, comment nous en sommes-nous sortis en 2007 ? C'est l'année la plus chargée que nous ayons vécue au Journal canadien de cardiologie, avec une importante augmentation du nombre de soumissions. Cependant, comme je l'ai souligné dans les numéros précédents, cette augmentation des soumissions ne s'est pas associée à une diminution suffisante des taux d'acceptation pour maintenir le délai moyen souhaité entre l'acceptation d'un article et sa words, the number of accepted papers awaiting publication increased. Moreover, there were challenges for our publisher as the total advertising revenue became limited. Because commercial viability of The Canadian Journal of Cardiology (as for most medical journals) is dependent on advertising revenue, action was necessary. Accordingly, as we indicated one year ago, the plan for 2008 was to decrease the number of issues published from 14 to 12 per year. It was also necessary to limit the number of pages published per issue. These two decisions have obviously complicated the situation concerning the number of papers awaiting publication and the time to publication. However, we did institute several strategies to deal with these issues. First, we began to accept submission of Case Reports and Images in Cardiology for online publication only to provide more opportunity to publish scientific papers in each issue. We also offered authors with accepted Case Reports and Images papers the opportunity to have their articles published online (unfortunately, not many accepted our invitation). We also instituted a submission charge, which seems to have had the anticipated impact of decreasing the number of submissions. Finally, more recently, we instituted a plan to offer authors of accepted papers the option of having their article published online with open access. We will be evaluating this initiative over the coming months. Everyone is committed to getting the accepted papers into the cited literature as soon as possible. I certainly apologize to all those authors waiting for more than six months (our stated goal) after final acceptance to have their papers published.

So what happened in 2008? We had a decrease in the number of papers submitted and have continued to push down the acceptance rate. Our citation impact factor for 2007 increased and is now at the highest level ever - and I have reason to expect that it will increase again for 2008. Importantly, this is not just because we published fewer papers; it also reflects a continuing high number of citations. It is my belief that we are continuing to attract higher quality papers, making the future look bright. We do have this short-term challenge to decrease our back$\log$ of papers and we are working hard to achieve that.

As usual, I am indebted to many people who work effectively to make the Journal function. But none are more important than the reviewers who make it possible to select the best work for publication. The complete listing of reviewers during 2008 appears elsewhere in this issue. To all these individuals, a heartfelt 'thank you'.

Doing reviews in a timely manner is also important. Our goal is to provide authors with an initial decision within 30 days of submission. publication. Autrement dit, le nombre d'articles acceptés attendant d'être publiés a augmenté. De plus, notre éditeur affronte aussi un défi, car le revenu de publication total est limité. Puisque la viabilité commerciale du Journal canadien de cardiologie (comme celle de la plupart des revues scientifiques) dépend des revenus de publication, il fallait agir. Ainsi, comme nous l'avions annoncé il y a un an, en 2008, nous avons fait passer le nombre de publications de 14 à 12 . Nous devions également limiter le nombre de pages publiées par numéro. De toute évidence, ces deux décisions ont compliqué la situation pour ce qui est du nombre d'articles en attente d'être publiés et du délai avant la publication. Cependant, nous avons adopté plusieurs stratégies pour régler ces problèmes. D'abord, nous avons commencé à accepter les soumissions de rapports de cas et d'images en cardiologie afin de les publier en ligne et d'accroître le nombre d'articles scientifiques dans chaque numéro. Nous avons également offert aux auteurs dont le rapport de cas ou l'image en cardiologie avait déjà été accepté de les publier en ligne (malheureusement, ils ne sont pas nombreux à avoir accepté notre invitation). Nous avons également exigé des frais de soumission, ce qui semble avoir eu l'effet anticipé de réduire le nombre de soumissions. Enfin, plus récemment, nous avons commencé à offrir aux auteurs d'articles acceptés de publier ces articles en ligne et d'y donner libre accès. Nous évaluerons cette initiative au cours des prochains mois. Nous voulons tous que les articles acceptés fassent partie des publications citées le plus rapidement possible. Je m'excuse auprès de tous les auteurs qui attendent plus de six mois (notre objectif établi) après l'acceptation finale pour que leur article soit publié.

Alors, que s'est-il passé en 2008 ? Nous avons subi une diminution du nombre d'articles soumis et avons continué de réduire le taux d'acceptation. Notre facteur d'impact de citations en 2007 a augmenté et a atteint le taux le plus élevé jamais enregistré, et j'ai raison de croire qu'il augmentera encore en 2008. Qui plus est, ce n'est pas simplement parce que nous avons publié moins d'articles, mais c'est aussi un reflet du nombre constant et élevé de citations. J'ai l'impression que nous continuons d'attirer des articles de meilleure qualité, ce qui fait que l'avenir s'annonce bien. Nous devons relever le défi à court terme de réduire notre arriéré d'articles et travaillons à y parvenir.

Comme toujours, je suis redevable à bien des gens qui travaillent avec efficacité à s'assurer que le Journal fonctionne. Toutefois, personne n'est plus important que les réviseurs qui permettent la sélection 
We are not meeting this target, although our median time to decision is less than 40 days, which certainly compares well with other journals. Below is a list of reviewers who completed their reviews and submitted them within one day. This is a remarkable record and some of these individuals appear in this list year after year. Thank you!

This is the time when we also express our appreciation to members of the Editorial Board who have completed their term, and welcome the individuals who have recently been appointed by the Canadian Cardiovascular Society for a three-year term. I look forward to working with the new Board members to continue the improvement of the Journal.

This coming year will be my last as Editor-in-Chief of The Canadian Journal of Cardiology. Currently, there is an ongoing search for my replacement; hopefully, this individual will be prepared to begin a period of overlap in July, 2009. I have considered it to be a major privilege to be the Editor of The Canadian Journal of Cardiology and, certainly, I will miss it. But 13 years is a long time, and the Journal will benefit from fresh eyes and new blood.

Finally, I take this opportunity to wish a very happy and healthy 2009 to our readers and to all those who contribute to the success of the Journal.

Eldon R Smith Editor-in-Chief

During 2008, the following individuals completed a review within one day of the request. What an outstanding achievement - we appreciate it!

Sandeep Aggarwal
John Boyd
Jeff Burton
Jonathan Choy
Richard Cook
François Dagenais
Hisham Dokainish
Hank Duff*
Thomas Forbes
Jacques Genest Jr
Anne Gillis
Steven Grover
Jeff Healey
Robert Hegele
Padma Kaul
Iqwal Mangat
Evangelos Michelakis
Randy Moore
Andrew Pipe
Christopher Simpson
Donald Smyth
John Tyberg
Andrew Warren
David Waters
* completed four reviews, all within one day

The views expressed on this page are those of the Editor-in-Chief and are not intended to reflect the opinions of the Canadian Cardiovascular Society or Pulsus Group Inc. des meilleurs travaux à publier. La liste complète des réviseurs pour 2008 figure ailleurs dans ce numéro. Je tiens à remercier chacun d'eux du fond du cœur !

Il est également important d'effectuer les révisions rapidement. Nous visons transmettre notre première décision aux auteurs dans les 30 jours suivant la soumission. Nous ne respectons pas cet objectif, mais le temps médian avant de rendre une décision est de 40 jours, ce qui se compare bien avec les autres revues scientifiques. Vous trouverez ci-dessous une liste des réviseurs qui ont effectué leur révision et l'ont soumise en une journée. C'est un record remarquable, et certains de ces réviseurs paraissent sur cette liste année après année. Merci !

C'est aussi en cette période que nous remercions les membres du comité de rédaction qui ont terminé leur mandat et que nous souhaitons la bienvenue à ceux qui ont été nommés par la Société canadienne de cardiologie pour un mandat de trois ans. J'ai hâte de travailler avec les nouveaux membres du comité pour poursuivre l'amélioration du Journal.

L'année qui s'annonce sera ma dernière à titre de rédacteur en chef du Journal canadien de cardiologie. Nous sommes actuellement à la recherche de quelqu'un pour me remplacer. J'espère que cette personne sera prête à entreprendre une période de chevauchement en juillet 2009. J'ai toujours ressenti que c'était un énorme privilège que d'être rédacteur en chef du Journal canadien de cardiologie et c'est une fonction qui, sans aucun doute, me manquera. Mais 13 ans, c'est long, et le Journal tirera profit de nouveaux yeux et de sang neuf.

Enfin, je profite de l'occasion pour souhaiter une année 2009 sous le signe du bonheur et de la santé à nos lecteurs et à tous ceux qui ont collaboré au succès du Journal.

Eldon R. Smith

Rédacteur en chef

En 2008, les personnes suivantes ont effectué une révision dans la journée suivant la demande. Quelle réalisation remarquable! Nous leur en savons gré.

\author{
Sandeep Aggarwal \\ John Boyd \\ Jeff Burton \\ Jonathan Choy \\ Richard Cook \\ François Dagenais \\ Hisham Dokainish \\ Hank Duff* \\ Thomas Forbes \\ Jacques Genest Jr \\ Anne Gillis \\ Steven Grover \\ Jeff Healey \\ Robert Hegele \\ Padma Kaul \\ Iqwal Mangat \\ Evangelos Michelakis \\ Randy Moore \\ Andrew Pipe \\ Christopher Simpson \\ Donald Smyth \\ John Tyberg \\ Andrew Warren \\ David Waters
}

*a effectué quatre révisions, toutes en une journée

Le présent point de vue n'engage que le rédacteur en chef et ne reflète pas nécessairement celui de la Société canadienne de cardiologie ou de Pulsus Group Inc. 